\title{
EFFECTS OF THYMIDINE AND 2-D-DEOXYGLUCOSE ON INSULIN-LIKE GROWTH FACTOR BINDING PROTEIN-1 (IGFBP-1) AND ERYTHROPOIETIN SECRETION IN HEPG2 CELLS
}

\author{
Junko Tanaka, Yoshio Murakami, Masateru Nishiki, Kunio Koshimura and Yuzuru Kato \\ First Division, Department of Medicine, Shimane Medical University, Izumo 693, Japan
}

\begin{abstract}
Effects of thymidine and 2-D-deoxyglucose on insulin-like growth factor-binding protein-1 (IGFBP-1) and erythropoietin (Ep) secretion were investigated in HepG2 cells. The maximal insulin-like growth factor-I (IGF-I) binding capacity was obtained at confluency, while Ep production was dominant in the proliferating stage and declined at confluency. Treatment with high concentraion of thymidine inhibited Ep production as well as proliferation of HepG2 cells, while IGFBP-1 production was increased by thymidine treatment. Addition of 2-D-deoxyglucose decreased viable cell number and Ep production and increased medium IGFBP-1 levels. These findings suggest that IGFBP-1 and Ep productions are linked to cell proliferation and that IGFBP-1 production is dominant in quiescent cells in HepG2 cells.
\end{abstract}

Insulin-like growth factor-I (IGF-1) plays a cruicial role for fetal development. The biological actions of IGF-I is regulated mainly by binding to IGF binding proteins because growth hormone has a limited role in fetal growth and IGF-1 production (4). It has been reported that IGHBP1 concentration is increased in intrauterine growth retardation $(7,13)$. The increase in IGFBP-1 could decrease availability of IGF-1 and consequently affect fetal development. The mechanisms of the increase in IGFBP-1 levels remain to be elucidated.

HepG2 cell has been a reliable model for numerous hepatocyte metabolic functions, including hepatic protein production and insulin regulation of IGFBP-1 production (5). The cells also secrete erythropoietin (Ep) in an oxygendependent manner, indicating the cells possess the nature of fetal hepatocytes.

Here we report the effects of blocking DNA

Correspondence to: Dr. Yoshio Murakami at the above address. Tel +81-853-23-2111; Fax: +81-85323-8650 synthesis with high concentration of thymidine and a consequent inhibition of cell proliferation on the productions of IGFBP-1 and Ep in HepG2 cells as a model of fetal hepatocyte. Effects of low glucose concentration and of 2-D-deoxyglucose on the secretion of these proteins as well as cell proliferation were also studied.

HepG2 cells were obtained from RIKEN cell bank, Wako, Saitama, Japan. The cells were cultured in DME supplemented with 10\% FCS, penicillin $(100 \mathrm{IU} / \mathrm{mL})$ and streptomycin $(100$ $\mu \mathrm{g} / \mathrm{mL}$ ). In Experiment I, $0.25,0.5,1$, and $2 \times 10^{5}$ cells $/ \mathrm{mL}$ were plated on 24-well dishes $(1 \mathrm{~mL} /$ $2 \mathrm{~cm}^{2}$ ). The culture medium was changed every 2 days. In Experiment II, $0.5 \times 10^{5}$ cells $/ 2 \mathrm{~cm}^{2}$ were plated on 24-well dishes. Two days after plating, when the culture was $60-70 \%$ confluency, the cells were treated with $0.1,1$, and $10 \mathrm{mM}$ thymidine. The culture medium with or without thymidine was changed every 2 days. At the designated days, the conditioned medium was aspirated and stored at $-20^{\circ} \mathrm{C}$ for IGFBP-1 and Ep assays, and the remaining cells were submitted to determination of viable cell numbers. In Exper- 
iment III, two days after plating at the density of $0.5 \times 10^{5}$ cells $/ 2 \mathrm{~cm}^{2}$, FCS was substituted with $0.1 \%$ BSA, and the cells were further cultured for 48 hours. The serum-free medium contained 25 $\mathrm{mM}$ glucose, $5.5 \mathrm{mM}$ glucose, or $5.5 \mathrm{mM}$ glucose plus $5.5 \mathrm{mM}$ 2-D-deoxyglucose. The medium was aspirated and stored for IGFBP-1 and Ep measurements. Viable cell determination was undertaken in serum-free medium containing $25 \mathrm{mM}$ glucose.

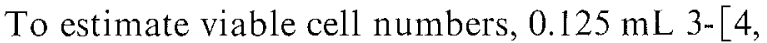
5-dimethylthiazol-2-yl]-2, 5-diphenyltetrazolium bromide (MTT) solution $(5 \mathrm{mg} / \mathrm{mL})$ was added to the culture $\left(0.5 \mathrm{~mL} / 2 \mathrm{~cm}^{2}\right)$ and was incubated for $4 \mathrm{~h}$. Then, the cells were lysed by addition of $0.5 \mathrm{~m}$ lysis buffer $(50 \% \mathrm{~N}, \mathrm{~N}$-dimethylformamide, $20 \%$ SDS, $2 \%$ acetic acid, $0.025 \mathrm{~N} \mathrm{HCl}, \mathrm{pH} 4.7$ ) and incubation at $37^{\circ} \mathrm{C}$ for $16 \mathrm{~h}$. The mixture $(0.225 \mathrm{~mL})$ was transferred into 96 well plates and the absorption at $550 \mathrm{~nm}$ (background: $620 \mathrm{~nm}$ ) was obtained by a spectrophotometer.

HepG2 cell-conditioned medium $(0.1 \mathrm{~mL})$ and ${ }^{125}$ I-IGF-I $(10,000 \mathrm{cpm})$ were mixed in $50 \mathrm{mM}$ Tris- $\mathrm{HCl}$ containing $0.5 \%$ BSA ( $\mathrm{pH} 7.4$ ) in a final volume of $0.5 \mathrm{~mL}$, and were incubated at $4^{\circ} \mathrm{C}$ for $16 \mathrm{~h}$. One $\mathrm{mL}$ of $1 \%$ activated charcoal was added and the mixture was further incubated at $4{ }^{\circ} \mathrm{C}$ for $30 \mathrm{~min}$, followed by centrifugation at $3000 \mathrm{rpm}$ at $4^{\circ} \mathrm{C}$ for $30 \mathrm{~min}$. The radioactivity of the supernatant was counted by a gamma counter to determine bound ${ }^{125} \mathrm{I}$-IGF-I. Non-conditioned medium was assayed in parallel and was subtracted from the bound radioactivity to determine specific IGF-I-binding activity.

IGFBP-1 and Ep levels were determined by a commercial IRMA kit (Diagnostic Systems, Webster, Texas, USA), and a RIA kit (Nippon DPC Co., Tokyo, Japan), respectively, according to the manufacturers' recommendations. Standard preparations were dissolved with non-conditined medium to exclude non-specific bindings. Thymidine and glucose concentrations in the sample did not affect the assays.

Statistical significance was evaluated by analysis of variance in combination with Duncan's new multiple range test. A $P$ value less than 0.05 was considered significant.

As shown in Fig. 1, viable cell number and medium IGF-I binding capacity were dependent on cell density, and the maximal IGF-I binding capacity was obtained at confluency. In contrast, Ep production was dominant in the proliferating stage and declined at confluency. Treatment with high concentraion of thymidine inhibited Ep production as well as proliferation of HepG2 cells in a dose-related manner, while IGFBP-1 production was increased by thymidine treatment (Fig. 2). As shown in Fig. 3, cell proliferation and Ep production were decreased at the glucose concentration of $5.5 \mathrm{mM}$ than at $25 \mathrm{mM}$. Medium IGFBP-1 level was $80.9 \%$ of those at $25 \mathrm{mM}$, while viable cell numbers were $56.6 \%$. Addition of 2-D-deoxyglucose $(5.5 \mathrm{mM})$ further decreased viable cell number and Ep production (Fig. 3). In contrast, medium IGFBP-1 level was rather increased by 2-D-deoxyglucose (Fig. 3).

HepG2 cells have been proved to be a useful model for studies of Ep and IGFBP-1 biosynthesis. Previous findings that Ep production was oxygen-dependent and that IGFBP-1 production was under a negative control by insulin (5) suggest that physiological mechanisms regulating Ep and IGFBP-1 biosynthesis are operating in the cells. In this study, we found that Ep production by HepG2 cells was prominent at the proliferating phase and declined after the culture reached confluency. Hagiwara et al. (8) observed that Ep production by human renal carcinoma cells showed a marked increase after the culture reached confluency. Thus regulating mechanisms of proliferation- or differentiation-associated Ep production are different among cell types. In contrast to Ep, IGFBP-1 production of HepG2 cells was maintained after confluency. These observations
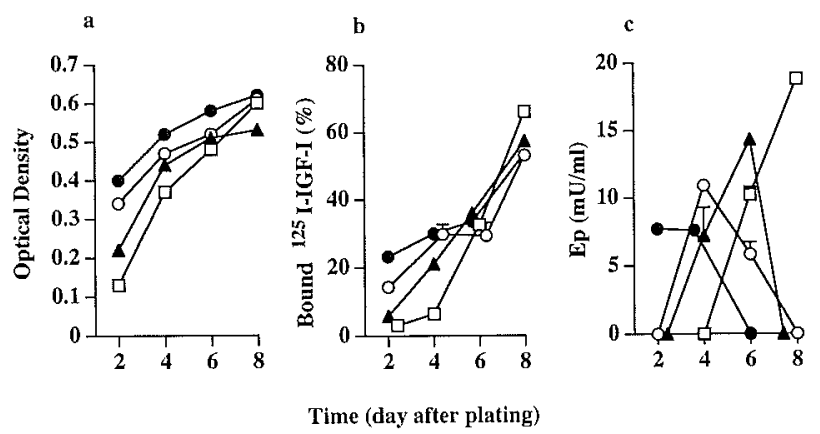

Fig. 1 Effect of cell density on viable cell number (a), medium IGF-I binding capacity (b), and Ep (c) levels in HepG2 cells. The cells were plated at the densities of 0.25 (open square), 0.5 (closed triangle), 1 (open circle), or 2 (closed circle) $\times 10^{5} / 2 \mathrm{~cm}^{2}$ on day 0 , and the culture medium was changed every 2 days. The IGF-I binding activity and Ep concentration in the medium were determined as described in Methods. The cells were submitted to MTT assay. Mean $\pm S E M$ values of 4 samples are shown. 

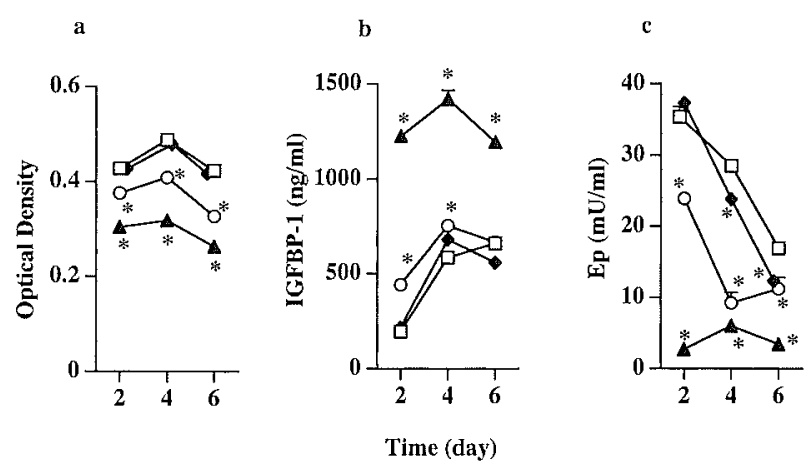

Fig. 2 Effect of thymidine on viable cell number (a), immunoreactive IGFBP-I (b), and Ep levels (c) in HepG2 cells. The cells were treated with 0.1 (closed diamond), 1 (open circle) or $10 \mathrm{mM}$ thymidine (closed triangle) on day 0 . Open square indicates a control. Mean values of 4 samples are shown. *: $P<0.01$.
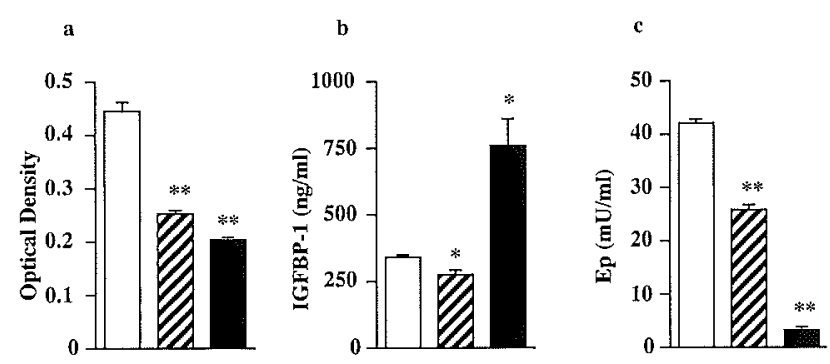

Fig. 3 Effects of glucose concentrations and 2-Ddeoxyglucose on viable cell number (a), medium IGFBP-1 (b), and Ep levels (c) in HepG2 cells. The cells were cultured for 48 hours in serum-free medium with $25 \mathrm{mM}$ glucose (open bar), $5.5 \mathrm{mM}$ glucose (hatched bar), or $5.5 \mathrm{mM}$ glucose plus 5.5 mM 2-D-deoxyglucose (closed bar). Mean \pm SEM values of 4 samples were shown. ${ }^{*}: P<0.05,{ }^{* *}: P<$ 0.01 .

suggest that Ep and IGFBP-1 productions are regulated by cell machinery in HepG2 cells and does not solely reflect the cell viability or the activity of non-specific protein synthesis.

Effects of cell proliferation on Ep and IGFBP-1 secretion were studied in HepG 2 cells treated with thymidine and 2-D-deoxyglucose in the present study. High concentration of thymidine inhibits DNA synthesis (2) through inhibiting ribonucleotide reductase (3). Both treatments decreased Ep secretion as well as cell proliferation during 2 days. Interestingly, we found that IGFBP-1 production was increased by thymidine treatment. IGFBP-1 production was clearly increased in the presence of 2-D-deoxyglucose. Lowering glucose concentration $(5.5 \mathrm{mM})$ alone slightly decreased medium IGFBP-1 levels while viable cell numbers were markedly decreased, suggesting an increase in IGFBP-1 secreted per cell. Cotterill et al. (6) previously reported that glucose concentrations at $4-12 \mathrm{mM}$ were stimulatory but a lower concentration ( $1 \mathrm{mM}$ ) was rather inhibitory on IGFBP-1 production in HepG2 cells. Because their findings were obtained in the experiments over $6 \mathrm{~h}$ period in confluent cells, it is plausible that the data mainly reflected metabolic effects of medium glucose concentrations but not effects related to cell proliferation. Lindgren et al. (10) observed that 2-D-deoxyglucose at doses of 1 to $10 \mathrm{mM}$ decreased IGFBP-1 secretion in the absence of glucose. Again the incubation time was $15 \mathrm{~h}$, and the viable cell numbers were not evaluated in their study. The observation of Mohn et al. (11) that insulin treatment of H35 rat hepatoma cells induced cell proliferation and rapid decrease in IGFBP-1 expression support our hypothesis that IGFBP-1 biosynthesis is linked to cell proliferation. There might be a com-

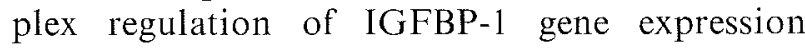
because IGFBP-1 gene was one of the immediateearly genes specifically expressed in regenerating rat liver in vivo (11). Further studies are necessary to clarify reasons of the discrepancy between the in vivo and in vitro findings.

Several intracellular factors are known to influence IGFBP-1 production in HepG2 cells. It was demonstrated that protein kinase $\mathrm{C}$ played a tonic inhibitory effect (9) and that cycloheximidesensitive labile proteins might contribute to maintain IGFBP-1 promotor activity and turnover of IGFBP-1 mRNA (12). However, the cellular mechanisms linking cell proliferation and IGFBP-1 production remains to be elucidated. It has been reported that IGFBP-1 levels in human amniotic fluid were negatively correlated with lecithin to sphingomyelin ratios, an index of fetal maturity (1). In intrauterine growth retardation associated with maternal diabetes mellitus, IGFBP-1 concentrations in the cord sera were higher than control (7). It was also reported that serum IGFBP-1 levels were increased in small for gestational age fetal rats (13). Taken together, it might be possible that an increase in IGFBP-1 levels in intrauterine growth retardation result from the increase in hepatic IGFBP-1 biosynthesis associated with growth impairment of the liver. 
In conclusion, it was suggested that IGFBP-1 and Ep productions are linked to cell proliferation in HepG2 cells. It might explain the increase in IGFBP-1 in the fetus with intrauterine growth retardation.

\section{Acknowledgements}

The authors are grateful to Nippon DPC Co. for providing us with Ep RIA kits. This work was partly supported by the Ministry for Health and Welfare, Japan.

Received 27 July, 1998; and accepted I September 1998

\section{REFERENCES}

1. Baxter R. C., Martin J. L. and Wood M. H.(1987) Two immunoreactive binding proteins for insulin-like growth factors in human amniotic fluid: Relationship to fetal maturity. J. Clin. Endocrinol. Metab. 65, 423-431

2. Bostock C. J., Prescott D.M. and Kirkpatrick J. B. (1971) An evaluation of the thymidine block for synchronizing mammalian cells at the G1-S border. Exp. Cell Res. 68, 163-168

3. Brown N. C. and Reichard P.(1969) Role of effector binding in allosteric control of ribonucleoside diphosphate reductase. J. Mol. Biol. 46, 39-5.5

4. Browne C. A. and Thorburne G.D.(1989) Endocrine control of fetal growth. Biol. Neonate 55, 331-346

5. Conover C. A. and LeE P.D.K.(1990) Insulin regulation of insulin-like growth factor-binding protein production in cultured HepG2 cells. J. Clin. Endocrinol. Metab. 70, 1062-1067

6. Cotterill A. M., Cowell C.T. and Sillink M.(1989) Insulin and variation in glucose levels modify the secre- tion rates of the growth hormone-independent insulin-like growth factor binding protein-1 in the human hepatoblastoma cell line Hep G2. J. Endocrinol. 123, R17-R20

7. Hall K., Hansson U., Lundin G., Luthman M., Persson B., Póvoa G., Stangenderg M. and Ö́fyerholm U.(1986) Serum levels of somatomedins and somatomedin-binding protein in pregnant women with type I or gestational diabetes and their infants. J. Clin. Endocrinol. Metab. 63, 1300-1306

8. Hagivara M., Pincus S. M., Chen I.-L., Beckman B. S. and FiSHER J.W.(1985) Effects of dibutyryl adenosine 3', 5 '-cyclic monophosphate on erythropoietin production in human renal carcinoma cell cultures. Blood 66, 714-717

9. Lee P. D. K., Abdel-Maguid L. S. and Snuggs M. B. (1992) Role of protein kinase-C in regulation of insulinlike growth factor-binding protein-1 production by HepG2 cells. J. Clin. Endocrinol. Metab. 75, 459-464

10. Lindgren B. F., Isaksson M., Stern I. and Hall K.(1993) Insulin-like growth factor binding protein-1 from Hep G2 cells is potently inhibited by the truncated IGF-I analogue des-(1-3) IGF-I. Acta Endocrinol. 128, 81-87

11. Mohn K. L., Melby A. E., Terawi D. S., Laz T. M. and TAUB R.(1991) The gene encoding rat insulinlike growth factor-binding protein 1 is rapidly and highly induced in regenerating liver. Mol. Cell. Biol. 11, 1393-1401

12. Oor G. T., Brown D. R., Suh D.-S., Tseng L. Y. -H. and Rechler M. M.(1993) Cycloheximide stabilizes insulinlike growth factor-binding protein-1 (IGFBP-1) mRNA and inhibits IGFBP-1 transcription in H4-II-E rat hepatoma cells. J. Biol. Chem. 268, 16664-16672

13. Unterman T., Lascon R., Gotway M. B., Oehler D., Gouris A., Simmons R. A. and Ogata E. S.(1990) Circulating levels of insulin-like growth factor binding protein1 (IGFBP-1) and hepatic mRNA are increased in the small for gestational age (SGA) fetal rat. Endocrinology 127, 2035-2037 